\title{
Remote teaching and learning during COVID-19 "lockdown" period in Malaysia: one institution's experience
}

\author{
Azlini Ismail*
}

Department of Fundamental Dental and Medical Sciences, Kulliyyah of Dentistry, International Islamic University Malaysia, 25200 Kuantan, Pahang, Malaysia

\begin{abstract}
The coronavirus disease (COVID-19) has prompted significant changes for most programs' teaching methods worldwide, especially during the "lockdown" period. Most education institutions in Malaysia were indefinitely closed, with the teaching and learning activities were resumed remotely. This letter highlights Kulliyyah of Dentistry, International Islamic University Malaysia's approaches in handling our teaching and learning activities (i.e., lectures, tutorials, seminars, practical, and the assessment), as well as the challenges faced by lecturers and students during the previous "lockdown" period.
\end{abstract}

Keywords: COVID-19, e-learning, Malaysia, remote, teaching and learning

Received:
2 March 2022
Revised:
2 March 2022
Accepted:
4 March 2022
Published Online:
4 March 2022 c2
How to cite this article:
Ismail, A. Remote teaching and
learning during COVID-19
“lockdown” period in Malaysia:
one institution's
experience. IIUM Journal of
Orofacial and Health
Sciences, 3(1), 156-158.
https://doi.org/10.31436/ijoh
S.v3i1.132
Article DOI:
10.31436/ijohs.v3i1.132
*Corresponding author
Address: Department of
Fundamental Dental and
Medical Sciences, Kulliyyah of
Dentistry, International Islamic
University Malaysia, Kuantan,
Pahang, Malaysia.
Telephone: +6014-5010081
Email: dr_azlini@iium.edu.my

Dear Editor,

The coronavirus disease (COVID-19) has instigated a nationwide "lockdown" in Malaysia which began on 18 March 2020 upon the Movement Control Order, issued by the government. Even though the whole country was not in a total lockdown, many sectors have been badly affected including the education sector, in which all education institutions were indefinitely ordered for closure by the government (Ismail et al., 2021). Because of that, education institutions were inevitably urged to resume teaching and learning activities remotely via online mode.
Kulliyyah of Dentistry (KOD), International Islamic University Malaysia (IIUM) is a dental faculty (kulliyyah) which is located in Kuantan, Pahang, a state in the East Coast of Malaysia. During that period, the Kulliyyah have consolidated on the following approaches in order to advocate the Ministry of Higher Education's order for remote e-learning:

1. Asynchronous lectures: KOD utilized Google

Classroom (https://classroom.google.com/u/0/ h) as a platform to arrange the 
conduct of each course. Students and all co-teachers were invited to join their respective Google Classroom. Usually, lecturers uploaded their recorded teaching videos into the Google Classroom before their respective sessions in the timetable. Most students were in favour of this approach as they can listen to the recorded lecture at their own suitable times. In this way, students can "pause" and "re-play" the lecture as they like. This has helped them to discern and process all information, especially the intricate concepts in which they might have missed during a one-off, face-to-face class session.

2. Synchronous seminars, tutorials, and discussions: The use of high internet bandwidth meeting platforms like Google Meet (https://meet.google.com/) and Zoom (https://zoom.us/) were reserved for seminars, tutorials, and discussions. The usage of these platforms was usually kept at optimal, taking into consideration of those students with internet difficulties.

3. Practical: Most laboratory practical sessions were postponed, except for those pre-recorded practical demonstration and experiment that involves simulations software which is free to be accessed and used by the students, i.e., RatCVS and OBSIM software in pharmacology course. Each student was given the chance to experience to conduct the experiment by using their own devices. Unfortunately, some software was not designed to be used in smartphones, thus students without desktop or laptop might not be able to use them. In order to ensure the successful conduct of simulation experiments, the session usually requires a well-prepared step-by-step student's instructions manual.

4. Clinical session: All clinical sessions were postponed during this period.

5. Assessment: For continuous assessment, online assessment tools like Quizizz (https://quizizz.com/), Kahoot (https://kahoot.com/), Google Form (https://www.google.com/forms/ab out/) and "Poll" function in Telegram (https://web.telegram.org/z/) were utilized. These online assessment tools are convenient and freely available to both students and lecturers. In addition, these tools are embedded with a detailed performance analysis feature which is very convenient for getting the assessment marks. However, for examinations, the Kulliyyah utilized our university's e-learning platform, iTaLeem

(https://italeemc.iium.edu.my/).The running of the examination through iTaLeem was aided with Zoom platform for monitoring.

In view of these newly employed approaches, we experienced some challenges in conducting remote online teaching and learning as both parties were still new and in the midst of adapting to this remote exercise. This remote teaching and learning exercise require lecturers to give extra efforts in making sure that at least a decent teaching video materials being uploaded in the Google Classroom prior to each class. As many of the lecturers were still amateur in online learning at that time, they were still not familiar with most of the online teaching tools. In view of this matter, the university had given us tremendous support by providing many in-house trainings prior to the start of remote online teaching and learning. In fact, local and international universities openly shared their online learning 
experiences and expertise intra- and inter-universities to address this sudden order to implement remote teaching and learning activities.

On the other side, students' limitation on the internet access had been one of the important challenges during the conduct of online learning. Despite the availability of the high-tech online learning tools, students who subscribed to a limited data plan encountered problems in downloading the large sized-video lectures. Those who lived in the rural areas did not have stable internet connection, and some unfortunate students did not even have any internet access. On that note, it seems that online learning was not convenient for the unfortunate students. Even for those with an access to internet, there were some technical hiccups that occur during the conduct of the live synchronous session, and these have somehow demotivated both lecturers and students for online learning. On this regard, the university has allowed those students who faced internet problems as well as those having unavoidable issues in studying at home to return to the university. This great initiative was indeed remarkable to curb from education inequalities should the situation not properly addressed at the early stage of remote teaching and learning exercise.

Other than that, we found that it was difficult to develop student-lecturer and student-student relationships with the conduct of remote teaching and learning. As university has been a place for students networking and social opportunities for so long, these social skills were somehow impeded in comparison to the usual face-to-face class interaction (Schleicher, 2020).
In lieu of our previous experience with full remote online teaching and learning, it requires for an utmost commitment from the lecturers and students. Despite these challenges, the first episode of remote teaching learning during COVID19 lockdown period has kickstarted the e-learning in many educational institutions, including us, and the era has been seen as the rising era of e-learning (Hermawan, 2021).

Now that all education institutions in Malaysia have re-opened, it seems appropriate to use blended learning approach (online plus face-to-face) as a precautionary measure to stop the spurting cases of COVID-19 in education institutions. Itis also important to decide on how many percent of the online learning component that is appropriate to be incorporated so that the learning objectives are fulfilled. At the same time, education institutions need to revamp the teaching and learning environment with e-learning to suit with the current generation.

Author's Information: Dr. Azlini Ismail was a part of IIUM Educator 4.0 team, which was appointed by the University to coordinate the e-learning activities at Kulliyyah of Dentistry, International Islamic University Malaysia.

\section{References}

Hermawan, D. (2021). The rise of e-learning in covid19 pandemic in private university: challenges and opportunities. IJORER: International Journal of Recent Educational Research, 2(1), 86-95.

Ismail, A., Ismail, N. H., Abu Kassim, N. Y. M., Lestari, W., Ismail, A. F., \& Sukotjo, C. (2021). Knowledge, perceived risk, and preventive behaviors amidst Covid-19 pandemic among dental students in Malaysia. Dentistry Journal, 9(12), 151.

Schleicher, A. (2020). The impact of COVID-19 on education: Insights from education at a glance $2020 . \quad$ Retrieved from: https://www.oecd.org/education/the-impact-ofcovid-19-on-education-insights-education-at-aglance-2020.pdf 